\title{
An Introduction to Two-Rate Taxation of Land and Buildings
}

\author{
Jeffrey P. Cohen and Cletus C. Coughlin
}

\begin{abstract}
When taxing real property at the local level in the United States, land and improvements to the land, such as buildings, are generally taxed at the same rate. Two-rate (or split-rate) taxation departs from this practice by taxing land at a higher rate than structures. This paper begins with an elementary discussion of taxation and the economic rationale for two-rate taxation. In theory, moving to a two-rate tax reduces the deadweight losses associated with distortionary taxation and generates additional economic activity. The paper also provides a history of two-rate taxation in the United States and a summary of studies attempting to quantify its economic effects. Discussions of the practical and political challenges of implementing two-rate taxation complete the paper.
\end{abstract}

Federal Reserve Bank of St. Louis Review, May/June 2005, 87(3), pp. 359-74.

"In my opinion, the least bad tax is the property tax on the unimproved value of land, the Henry George argument of many, many years ago.”

-Milton Friedman, as quoted in Mankiw (2004), 1976 Nobel Prize laureate in economics.

"The property tax is, economically speaking, a combination of one of the worst taxes-the part that is assessed on real estate improvements... and one of the best taxes-the tax on land or site value."

—William Vickrey (1999), 1996 Nobel Prize laureate in economics.

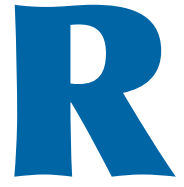

evenues from the taxation of real property play a key, and frequently controversial, role in the funding of elementary and secondary education as well as many other publicly provided services. Our focus is on one suggested improvement of property taxation known as "two-rate" or "splitrate" taxation. When taxing a specific parcel of real property in the United States, the same rate is usually applied to the land as well as to the improvements to the land, such as buildings. The opinions expressed by Nobel Prize winners Milton Friedman and William Vickrey are at the root of proposals to differentiate the taxing of land from the buildings on that land. Such proposals have attracted increasing attention from researchers and policymakers in Connecticut, Massachusetts, Virginia, and Pennsylvania in recent years. ${ }^{1}$

The two-rate proposal is a modification of the extreme case in which the only tax levied is on the value of land. Taxes on the value of buildings, as well as all other taxes, would be zero. Thus, the owners of buildings would no longer pay a property tax; only the owners of land would be taxed. Such a pure land tax approach was advocated by Henry George in a book published in 1879, Progress and Poverty. He argued that land should be taxed at 100 percent of its "rental value."2 George reasoned that the land value tax

1 Craig (2003) notes that over 700 cities worldwide use two-rate taxation of property.

2 O'Sullivan (2003, p. 154) defines land rent as "the annual payment in exchange for the right to use the land."

Jeffrey P. Cohen is an assistant professor of economics at the Barney School of Business, University of Hartford; he acknowledges the support of the Lincoln Foundation. Cletus C. Coughlin is deputy director of research and a vice president at the Federal Reserve Bank of St. Louis. Jason Higbee provided research assistance. The views expressed are those of the authors and do not necessarily reflect official positions of the Federal Reserve System or the Lincoln Foundation.

(c) 2005, The Federal Reserve Bank of St. Louis. 


\section{Cohen and Coughlin}

would increase efficiency (and the wealth of society) by allowing governments to abolish taxes on improvements to land, as well as eliminate all other forms of taxation. He also cited equity reasons for the "single tax" on land. ${ }^{3}$ Namely, increases in land value (exclusive of improvements) in the early 1900s were due primarily to an entire community's private-sector and publicsector economic activities rather than the actions of the specific land owner. Therefore, George argued, land owners should not benefit disproportionately from city growth, and the tax on land would allow for the redistribution of these unearned gains. ${ }^{4}$

A pure land tax, however, is not without some faults. First, it is not easy to measure the value of land net of improvements, and this would make it difficult for government to determine the amount of the land tax. This shortcoming of the pure land tax would also be present with the two-rate tax. Second, if a pure land tax were to capture all current and future rent from the landowners, the market value of the land would become zero. This would be equivalent to the government taking the land from landowners. Thus, people would have no incentive to hold land, leading to abandonment of the land, and likely resulting in governmental decisions about how the land should be used and by whom. Third, the change to a pure land tax would likely have significant redistributional effects, with large landowners likely incurring substantial adverse wealth effects. This effect, however, might be viewed by some as a virtue rather than a fault.

Compared with the pure land tax, the two-rate tax on land and buildings is a more general and, perhaps, more practical alternative. Instead of taxing land and structures at the same rate, as is the case with the conventional property tax, the two-rate tax would tax land at a higher rate than

\footnotetext{
3 George used the term "single tax" because he thought that a tax on unimproved land could yield sufficient revenues to finance all government spending. While his thinking was appropriate for the late nineteenth century, the revenue potential of land taxation is far less than the size of public spending today.

4 A discussion of the ethical arguments involving land taxation (i.e., Is such a tax just?) can be found in Fischel (1998) and Bromley (1998).
}

the structures on the land. This form of the tax would encourage improvements on relatively small lots of land because such improvements would be taxed at a lower rate than the land itself. The increased incentive for improving structures would lead to increased economic development. In the context of urban economic development, such a tax policy might reverse the trend of economic decay experienced by some cities. Moreover, because the tax rate on land using a two-rate tax would be less than the tax rate using a pure land tax, the potentially large changes in land prices would be mitigated somewhat. Thus, the size of adverse wealth effects would be reduced, which might help in reaching a political agreement to support a two-rate system.

In the next section, we provide an introduction to taxation. This general introduction provides the foundation for a discussion of land taxation and the two-rate tax. A history of two-rate taxation in the United States follows this discussion. Tworate taxation has been used in Pennsylvania, most notably in Pittsburgh. Next, we review a number of studies attempting to quantify the effects of tworate taxation. These studies include a case study of Pittsburgh as well as studies attempting to identify the potential effects of various tax-change proposals. This discussion is followed by an elaboration of the practical problems of implementing two-rate taxation. A summary of the political economy issues involved in land value taxation completes the body of our paper.

\section{THE WELFARE EFFECTS OF TAXATION USING DEMAND AND SUPPLY CURVES 5}

Demand and supply curves can be used to illustrate how taxes affect the behavior and the economic well-being of consumers and producers. The effect of taxation is one of the topics in what economists refer to as welfare economics. Before

\footnotetext{
5 Readers familiar with this material might want to proceed directly to the next section on land taxation. For readers desiring an elaboration of the material in this section, see Chapters 6 through 8 in Mankiw (2004).
} 


\section{Figure 1}

\section{Demand and Consumer Surplus}

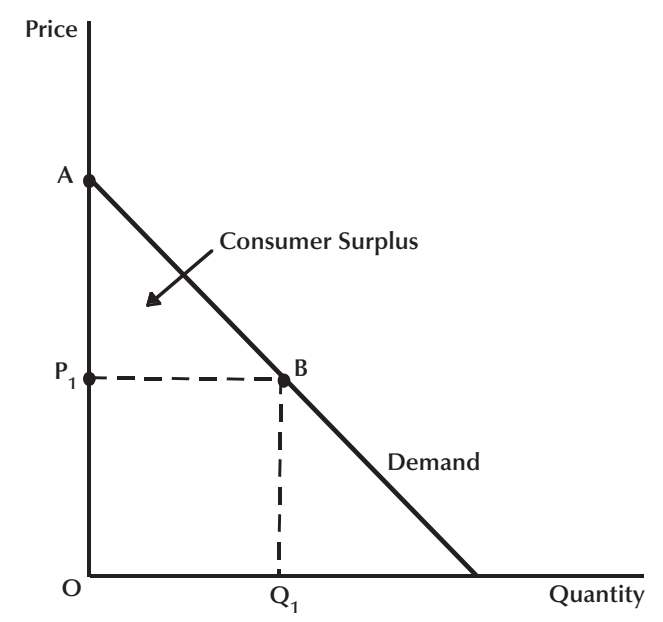

analyzing the effects of a specific tax, we must first introduce the concepts of consumer surplus, producer surplus, and efficiency.

\section{Consumer Surplus}

We begin by using a demand curve to measure consumer surplus. Consumer surplus is the amount that buyers are willing to pay for a good minus the amount they actually pay for it.

Figure 1 shows a hypothetical demand curve. Assuming a price per unit of $\mathrm{P}_{1}$, buyers would purchase $Q_{1}$ units of this good. Thus, the total expenditure by consumers on this good would be $\mathrm{P}_{1}$ times $\mathrm{Q}_{1}$ or, in terms of an area, the rectangle $\mathrm{OP}_{1} \mathrm{BQ}_{1}$.

The demand curve reveals how much consumers are willing to pay for the $\mathrm{Q}_{1}$ units. Moving rightward on the quantity axis from the origin, the value that consumers are willing to pay is reflected by the height of the demand curve. This reflects the assumption that the first unit is valued the most by consumers, the second unit somewhat less, and so on as one moves down the demand curve. Thus, the total amount that consumers are willing to pay for the $Q_{1}$ units is equal to the area of the four-sided figure $O A B Q_{1}$. The difference between what consumers are willing to pay and

\section{Figure 2}

\section{Supply and Producer Surplus}

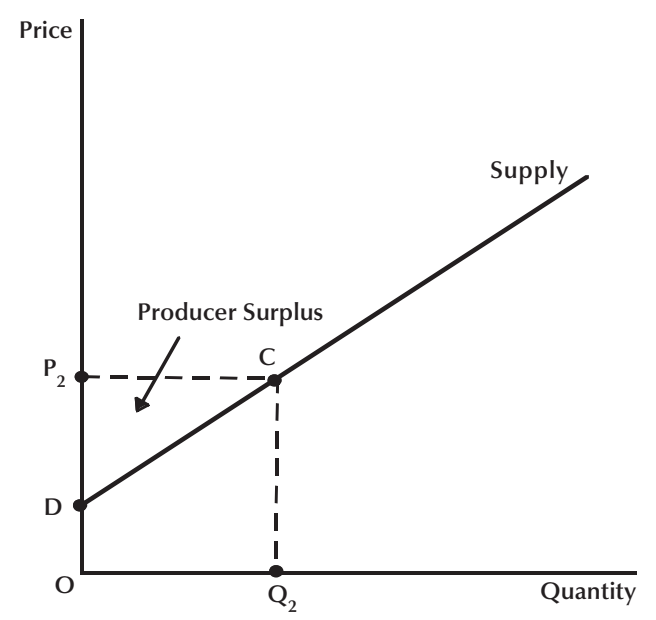

what they actually pay (i.e., consumer surplus) is represented by the triangular area $\mathrm{P}_{1} \mathrm{AB}$.

\section{Producer Surplus}

Turning to the supply side of this market, the concept of producer surplus can be illustrated using a supply curve. Producer surplus is the difference between actual compensation received by sellers for a given quantity of output (i.e., total revenue) and the minimum compensation sellers would require to provide that given quantity. Figure 2 shows a hypothetical supply curve. The positive slope of the supply curve reflects the assumption that the compensation to induce additional units of production increases as output increases. Assuming a price per unit of $\mathrm{P}_{2}$, producers would supply $Q_{2}$ units of this good. Thus, the total revenue would be $\mathrm{P}_{2}$ times $\mathrm{Q}_{2}$ or the area of the rectangle $\mathrm{OP}_{2} \mathrm{CQ}_{2}$.

The minimum compensation necessary to induce producers to supply $\mathrm{Q}_{2}$ is revealed by the supply curve. Moving rightward on the quantity axis from the origin, the minimum compensation is reflected by the height of the supply curve. Thus, the minimum compensation for $\mathrm{Q}_{2}$ units is equal to the four-sided area ODCQ ${ }_{2}$. The difference between the total revenue of producers and the minimum they must receive to produce (i.e., 


\section{Figure 3}

\section{Market Equilibrium: Consumer and Producer Surplus}

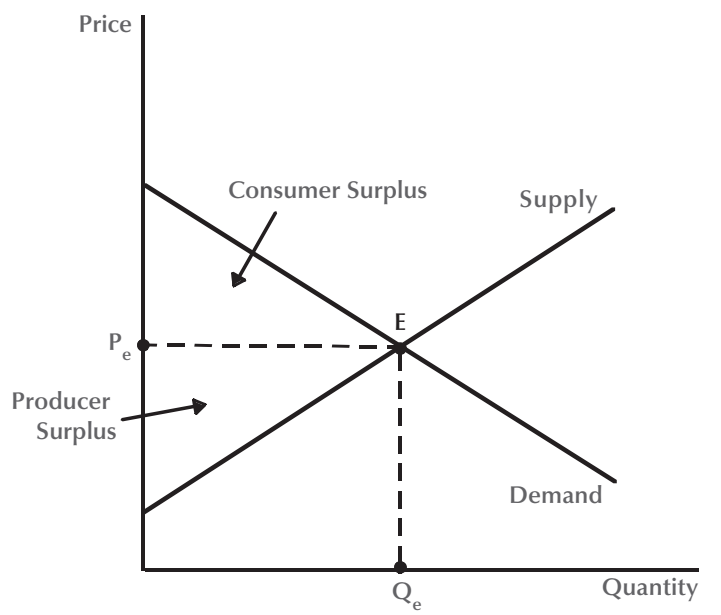

producer surplus) is represented by the triangular area $\mathrm{DP}_{2} \mathrm{C}$.

In equilibrium, the quantity consumers are willing to buy equals the quantity producers are willing to supply. The competitive equilibrium shown in Figure 3 reflects what economists term "economic efficiency." One key implication of economic efficiency is that total economic surplus, which is the sum of consumer and producer surplus, cannot be increased by either increasing or decreasing the output of this good. Increased output would cause the additional cost incurred by sellers to exceed the additional value to buyers, while decreased output would cause the additional value to buyers to exceed the additional cost incurred by sellers.

\section{Effects of Taxes}

Now let's examine the effect of taxes on this market. Taxes impose a wedge between what consumers pay and what producers receive. Assume a tax of $\$ 1$ per unit is levied on buyers of a particular good. Such a tax can be illustrated by shifting the demand curve downward by the size of the tax because consumers only care about their out-of-pocket expense in determining a desired quantity. This is shown in Figure 4 by

\section{Figure 4}

\section{Effects of a Tax Levied on Consumers}

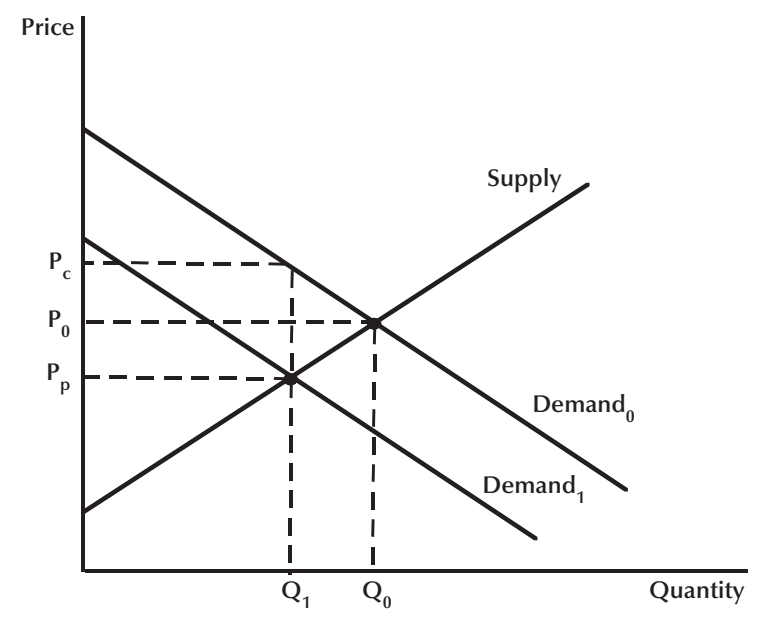

the shift in demand from Demand Do Demand $_{1}$. The new equilibrium quantity is $Q_{1}$, which is less than the original equilibrium of quantity of output. At $Q_{1}$, the price per unit received by producers is $\mathrm{P}_{\mathrm{p}}$ and the price paid by consumers is $\mathrm{P}_{\mathrm{c}}$. The difference in these two prices is $\$ 1$, which is the amount per unit received by the taxing authority. ${ }^{6}$ Note that, despite the fact that the tax is levied on consumers, both consumers and producers bear the burden of the tax. Consumers incur a reduction in consumer surplus because they are now paying a higher price per unit for a reduced quantity. Meanwhile, producers incur a reduction in producer surplus because they are now receiving a lower price per unit and producing less.

Does it matter in this case if producers had been taxed \$1 per unit of output rather than taxing consumers $\$ 1$ for every unit they purchased? The answer is no. This possibly surprising result is shown in Figure 5. Because the tax increases production costs by $\$ 1$ per unit, the supply curve is shifted upward by the size of the tax. Once again, the difference between the price paid by consumers, $\mathrm{P}_{\mathrm{C}}$, and the net price received by producers, $\mathrm{P}_{\mathrm{p}}$, is $\$ 1$. This tax wedge is identical to

\footnotetext{
6 To distinguish between the two prices, the price paid by consumers can be called the gross-of-tax price, while the price received by producers can be called the net-of-tax price.
} 


\section{Figure 5}

\section{Effects of a Tax Levied on Producers}

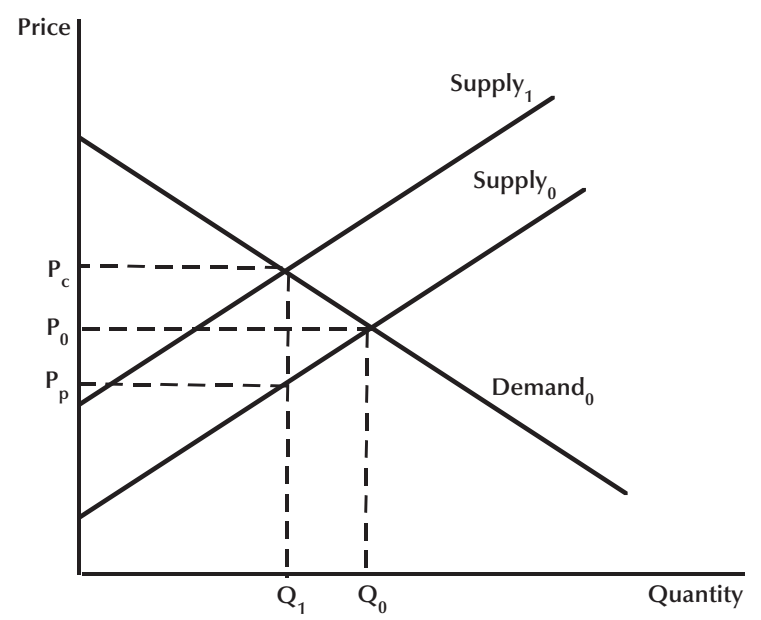

the tax wedge shown in Figure 4. Consequently, the equilibrium quantity, $Q_{1}$, in Figure 5 is the same quantity as in Figure 4. Given the identical price faced by consumers and the identical quantity, consumers bear the same burden, regardless of upon whom the tax is levied. An identical comment can be made concerning the tax burden of producers.

\section{Taxes and Welfare}

Next, let's examine the welfare consequences in more detail. Because Figures 4 and 5 generate identical results, we can simplify the analysis by not showing the curve that shifts. Figure 6 shows the same information as Figures 4 and 5. The $\$ 1$ tax per unit drives a $\$ 1$ wedge between what consumers pay and producers receive. This $\$ 1$ per unit is received by the government as tax revenue. In Figure 6, tax revenue is represented by the rectangle $\mathrm{P}_{\mathrm{p}} \mathrm{P}_{\mathrm{c}} \mathrm{AB}$ (or $\left.\left(\mathrm{P}_{\mathrm{c}}-\mathrm{P}_{\mathrm{p}}\right) \times \mathrm{Q}_{1}\right)$. Meanwhile, the tax imposes burdens on consumers and producers. The cost of taxation for consumers and producers reflects not only the amount paid to the taxing authority, but also the cost associated with transactions that no longer occur because the tax has made them "uneconomic." This latter point is due to the fact that, in nearly all cases, taxation causes consumers and producers to change their behavior.

\section{Figure 6}

\section{Deadweight Loss of a Tax}

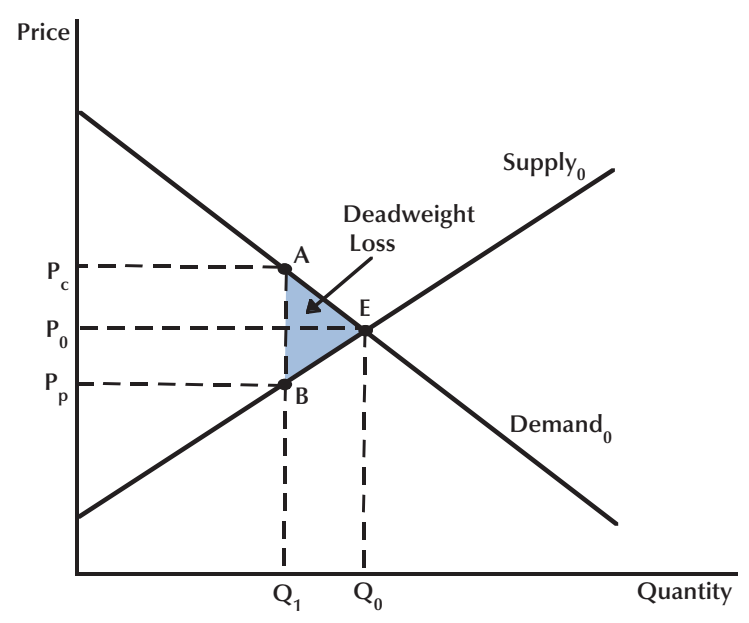

The tax burden for consumers is the reduction in consumer surplus. Due to the higher price and the reduced consumption, this loss is the foursided area $\mathrm{P}_{0} \mathrm{P}_{c} \mathrm{AE}$. The tax burden for producers is the reduction in producer surplus. Due to the lower price and the reduced production, this loss for producers is the four-sided area $\mathrm{P}_{\mathrm{p}} \mathrm{P}_{0} \mathrm{~EB}$. Note that some of the losses incurred by both consumers and producers reflect a transfer to the government. ${ }^{7}$ Overall, the net decline in national well-being is the triangle BAE, which is termed the deadweight loss (DWL) caused by the tax. This loss reflects the fact that taxation prevents some mutually beneficial exchanges between consumers and producers from occurring.

For a given tax, the distribution of the effects on economic well-being and the size of the DWL depend on how much quantity demanded and quantity supplied respond to the change in price stemming from the tax. A summary measure of this responsiveness is the price elasticity of demand (supply). The price elasticity of demand is the absolute value of the percentage change in

7 To simplify the analysis, we have assumed that the government programs funded by the tax revenues yield benefits that are equal to the losses incurred by consumers and producers associated with the tax payments. 


\section{Cohen and Coughlin}

quantity demanded divided by the percentage change in price. Larger values of the price elasticity of demand are associated with flatter slopes of the demand curve; conversely, smaller values of the price elasticity of demand are associated with steeper slopes of the demand curve. ${ }^{8,9}$ The same terminology and implications for slope are used for the price elasticity of supply, for which larger (smaller) values of the price elasticity of supply are associated with flatter (steeper) slopes of the supply curve.

The price elasticities of demand and supply affect the tax burdens imposed on consumers and producers. Exactly how is straightforward. Begin by envisioning a clockwise rotation of the demand curve around point $\mathrm{E}$ in Figure 6. In this case, the price elasticity of demand is becoming less elastic (more inelastic). With an unchanged supply curve, as the demand curve becomes less elastic, the price that consumers pay will rise as will the price that producers receive. Note that the tax wedge must remain constant. The end result is that the tax burden imposed on consumers rises relative to that of producers. In other words, holding all other things constant, as the price elasticity of demand decreases, the tax burden of consumers rises relative to that of producers.

Similar results occur when the price elasticity of supply becomes less elastic. With the demand curve unchanged, as the supply curve becomes less elastic, the price that producers will receive falls as will the price that consumers pay. Thus, the tax burden imposed on producers rises relative to that of consumers. In summary, as the price elasticity of demand (supply) decreases, the larger the relative tax burden of consumers (producers).

The economic intuition underlying this result is straightforward. In terms of their consumption, the less responsive consumers are to the higher

\footnotetext{
8 The price elasticity of demand at a specific point on a demand curve, for instance $\left(\mathrm{P}_{0}, \mathrm{Q}_{0}\right)$, is equal to the absolute value of $\mathrm{P}_{0} / \mathrm{Q}_{0}$ times $\Delta \mathrm{Q} / \Delta \mathrm{P}$. The latter term is the inverse of the slope of the demand curve. If a demand curve were to become flatter (steeper), the value of $\Delta \mathrm{Q} / \Delta \mathrm{P}$ would increase (decrease). Thus, the price elasticity of demand increases (decreases).

9 Economists refer to increasing values of the price elasticity of demand (supply) as being "more elastic" or "less inelastic" and decreasing values as being "less elastic" or "more inelastic."
}

price they pay as a result of a tax, the higher their relative tax burden. In other words, the tax burden of consumers is relatively more the less they change their behavior in response to higher prices. Similar reasoning pertains to producers. In terms of their production, the less responsive producers are to the lower (net) price they receive as a result of a tax, the higher their relative tax burden.

In addition to being related to the tax burdens of consumers and producers, the price elasticities of demand and supply affect the DWL of the tax. A tax creates a DWL because it causes buyers and sellers to change their consumption and production behavior. For a given tax, the larger the price elasticities of demand and supply, the larger are the changes in consumption and production. Thus, larger price elasticities of demand and supply are associated with larger DWLs.

\section{THE THEORY OF LAND TAXATION}

"Tax something, there will be less of itexcept land." (Harriss, 2003)

Land is different from most other goods. Namely, proponents of land taxation note that the supply of (unimproved) land, which is provided by nature, is fixed. In other words, the supply is perfectly inelastic. This implies that the supply curve for land is vertical, as shown in Figure 7. Recall that a tax on consumers of land (as well as a tax on consumers of any good, as outlined in the previous section) will shift the demand curve downward. Figure 7A shows a decline in demand from Demand ${ }_{0}$ to Demand ${ }_{1}$. Because the supply curve is vertical, shifting the demand curve downward implies that the new demand curve will intersect the supply curve at the same quantity of land as before the land tax (i.e., $Q_{0}$ ). As a result, the intersection of the new demand curve and supply curve will occur at a lower net-of-tax equilibrium price than before the land tax (i.e., $\mathrm{P}_{1}$ rather than $\mathrm{P}_{0}$ )—with no change in the equilibrium quantity of land. Further, note that the gross-of-tax price, $\mathrm{P}_{0}$, is identical to the price in the absence of the tax. The land tax has no effect on the allocation of productive resources. The 
result is that land owners bear the entire burden of the tax and there is no DWL with this land tax. ${ }^{10}$

A property tax on buildings, however, alters or distorts behavior away from that which would take place in a competitive economy without taxes. As seen in Figure 7B, because higher prices encourage producers to supply additional buildings, the supply curve for buildings slopes upward. The demand curve slopes downward for the same reason that the demand curve for land slopes downward-higher prices result in a decrease in the quantity of buildings demanded. A tax on consumers of buildings causes the demand curve to shift down by the amount of the tax. The end result is that some of the burden of the tax is borne by individuals who produce buildings (in the form of lower building prices) and fewer buildings are consumed in equilibrium. Thus, relative to the land tax case, the tax on buildings distorts behavior, leading to a DWL: The loss of consumer and producer surplus is greater than the revenue transferred to the government through the tax.

Moving from a traditional property tax (where land and buildings are taxed at one rate) to a two-rate tax (where land is taxed at a relatively higher rate) lowers DWL. If a goal is to keep total tax revenues unchanged, the tax on buildings can be lowered and the tax on land raised to achieve a revenue-neutral alternative. As a result, the distortionary (building) tax is decreased (i.e., in Figure 7B, the demand curve shifts upward from Demand ${ }_{1}$ ), while the neutral (land) tax is increased. The overall effect is to lower the DWL. One way to think of this reduction in DWL is that a change to a more efficient tax system is equivalent to a tax cut. A given amount of public services can be provided with a lower local tax burden. Despite the fact that tax revenues are unchanged, the tax burden is effectively lowered because of the decline in DWL.

A reduction of the DWL associated with the current system of property taxation, however, is not the only economic argument that can be

${ }^{10}$ O’Sullivan (2003, pp. 526-28) presents a somewhat different exposition of the market effects of land taxation but arrives at the same outcome that the equilibrium price of land falls by the amount of the tax, with the quantity of land in equilibrium unchanged.

\section{Figure 7}

\section{Taxing Land versus Taxing Buildings}
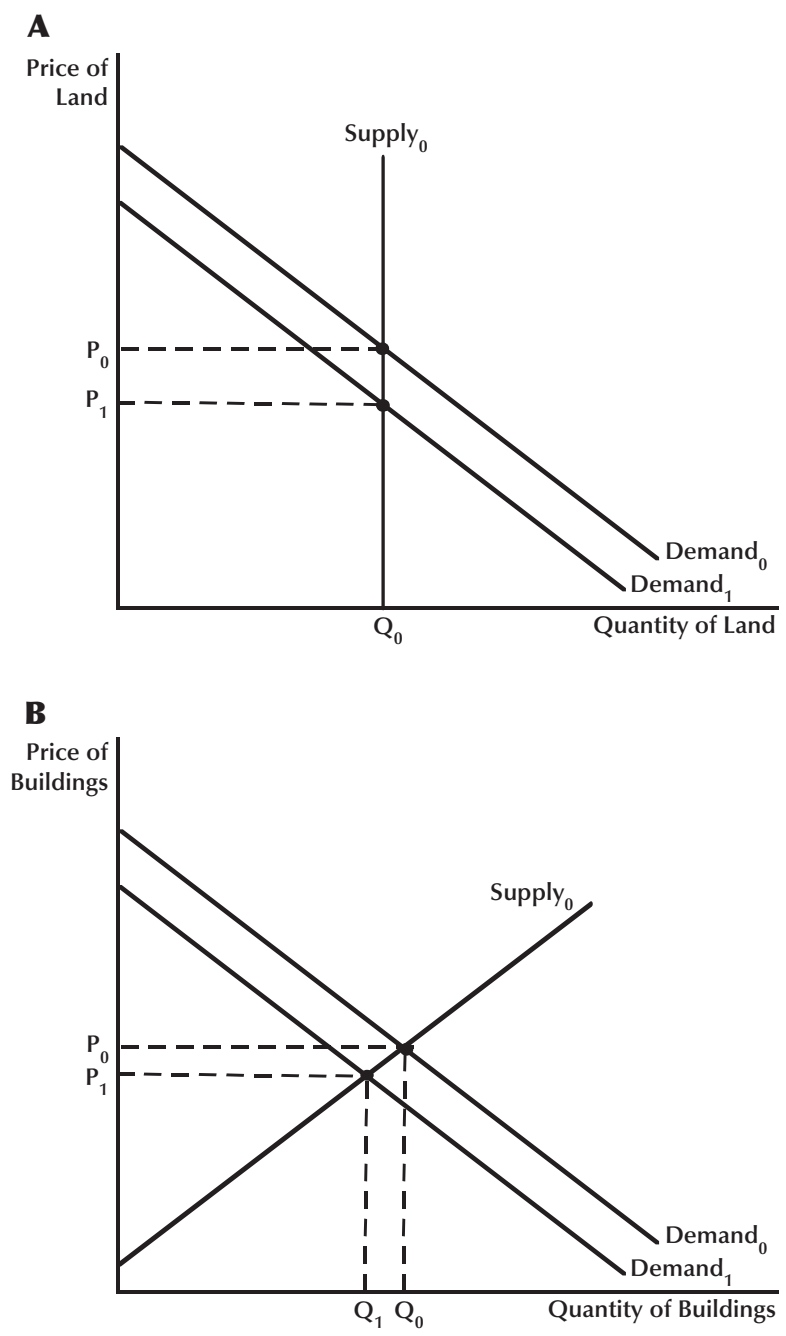

made to support increased tax rates on land and decreased tax rates on improvements. Mills (1998) has provided an analysis of the spatial equilibrium effects of single taxation. Specifically, Mills showed how productive activity throughout a hypothetical metropolitan area would be changed by a revenue-neutral switch from a conventional property tax (i.e., one that applies to both buildings [capital] and land) to a tax on land only. The switch causes capital and labor to be substituted for land. The more intensive use of capital and labor increases the productivity of each land 
Table 1

Mill Rates: Kauai County, Hawaii, Fiscal Year 2004 (July 2003-June 2004)

\begin{tabular}{lcccccccc} 
& Homestead & $\begin{array}{c}\text { Single } \\
\text { family }\end{array}$ & Apartment & $\begin{array}{c}\text { Hotel/ } \\
\text { resort }\end{array}$ & Commercial & Industrial & Agricultural Conservation \\
\hline Buildings & 3.64 & 4.5 & 8.15 & 8.15 & 8.15 & 8.15 & 4.5 & 4.5 \\
Land & 4.35 & 5.49 & 8.55 & 8.55 & 8.55 & 8.55 & 7.95 & 8.45
\end{tabular}

SOURCE: Tax Foundation of Hawaii; www.tfhawaii.org/taxes/property.html.

parcel, which tends to increase gross-of-tax land prices. ${ }^{11}$ With agricultural land remaining untaxed, the city expands. Due to the increased use of capital and labor on each land parcel, output in the metropolitan area expands-in fact, output increases at every location within the metropolitan area. Thus, as shown by Brueckner (2001), such a tax change would lead to denser patterns of land development and, therefore, inhibit metropolitan sprawl. Since land in many inner cities is currently underutilized, such denser land development would be desirable.

In a subsequent section of our paper, we take a closer look at the possible magnitudes of the economic effects of using two-rate taxation. A caveat mentioned by Mills is that the adjustment period associated with such a tax change might well be very long and require very large, albeit justified, investments.

\section{TWO-RATE TAXATION IN THE UNITED STATES}

Because real property taxes in the United States are generally levied by local taxing authorities, most examples of two-rate taxation are at the local level. The most frequently mentioned example involves the state of Pennsylvania and, specifically, the city of Pittsburgh. In 1979-80, Pittsburgh revamped its property tax system by raising tax rates on land to more than five times the rate on structures. From 1913 to 1979-80, Pittsburgh had a two-rate tax in place, with the tax rate on buildings being twice the rate on land

11 Technically speaking, the equilibrium gross-of-tax rent-distance function rises, while the net-of-tax rent-distance likely falls.
(Hartzok, 1997). ${ }^{12}$ According to the state's Taxation Manual (Pennsylvania Department of Community and Economic Development, 2002), Scranton is the other city in Pennsylvania that is authorized to charge lower tax rates on buildings than on land. ${ }^{13}$

Although recent state legislation authorized two local governments in Virginia to implement a two-rate tax, neither has adopted it (Brunori, 2004). The cities of Fairfax and Roanoke have the authority to tax property on land at a lower rate than the corresponding land; however, one stipulation of the legislation is that the tax on property may not be zero, thus precluding a pure land tax. ${ }^{14}$

A final example involves Hawaii, whose state legislature passed a two-rate tax in 1963. A major difference between the Hawaii legislation and the Pittsburgh legislation, however, is that in Hawaii the two-rate tax applied to all jurisdictions (Rybeck, 2000). Legislation in 1978 granted counties the authority to set their own local property tax rates. As of fiscal year 2004, though, Kauai was the only one of Hawaii's four counties to set

\footnotetext{
12 The Taxation Manual for Pennsylvania (2002) notes that all property owners in the state pay property taxes to the municipality, the corresponding county, and school district. Oates and Schwab (1997) also note that for the city of Pittsburgh, the presence of these school district and county property taxes that levy a "conventional property tax" imply that the net tax rate for land is greater than twice the rate for structures.

${ }^{13}$ Other governmental entities in Pennsylvania, such as third-class cities, boroughs, and third-class school districts coterminous with third-class cities, may also use two-rate taxation. For a discussion of the structure of different local levels of Pennsylvania government, see section 6 of volume 116 of the Pennsylvania Manual (2003): www.dgs.state.pa.us/pamanual/lib/pamanual/sec6/section6a.pdf.

${ }^{14}$ For a reproduction of the detailed Virginia legislation, see www.progress.org/cg/roan03.htm.
} 
higher tax rates for land than for buildings. ${ }^{15}$ As can be seen in Table 1, the differences in tax rates for many property classes for Kauai are small.

\section{EFFECTS OF TWO-RATE TAXATION}

A number of recent quantitative studies have examined the effects of implementing two-rate taxation. Quantitative studies are important for providing policymakers with estimates of the potential gains from shifting toward land as a tax base and some sense of the size of the distributional issues of such a change. To date, only one comprehensive study, focused on the consequences for Pittsburgh, has attempted to identify the actual effects of two-rate taxation. Generally speaking, existing quantitative studies have attempted to gauge the hypothetical effects of tworate taxation. Some of these latter studies have focused on the short-run initial effects, while others have attempted to identify the likely effects given the economic decisions that would ensue under the changed tax regime. In other words, the former studies consider only the initial redistribution of the property tax burden and, as a result, do not identify how differential rates on land and improvements are likely to induce more intensive use of land.

\section{The Pittsburgh Experience}

After Pittsburgh further increased the difference between the tax rate for land and the tax rate for buildings in 1979-80, the city experienced a substantial increase in building activity. Oates and Schwab (1997) provided suggestive evidence that Pittsburgh's change in tax rates played a major role in stimulating the building boom. ${ }^{16}$ They noted that this finding is surprising, however, because public finance theory suggests that increasing the land tax while leaving the buildings

\footnotetext{
${ }^{15}$ For the details of property tax rates for all four counties in Hawaii, see www.tfhawaii.org/taxes/property.html.

${ }^{16}$ Oates and Schwab also point out, however, that there was a major Pittsburgh revitalization effort (Renaissance II) underway in the late 1970s in an attempt to counteract the demise of the city's steel industry.
}

\section{Table 2 \\ Percent Change in Average Annual Value of Building Permits Between 1960-79 and 1980-89}

\begin{tabular}{lc} 
City & Percent change \\
\hline Akron & -34.4 \\
Allentown & -40.2 \\
Buffalo & -11.5 \\
Canton & -39.7 \\
Cincinnati & -27.2 \\
Cleveland & -31.8 \\
Columbus & 15.4 \\
Dayton & -14.4 \\
Detroit & -24.7 \\
Erie & -52.9 \\
Pittsburgh & 70.4 \\
Rochester & -30.6 \\
Syracuse & -43.2 \\
Toledo & -32.4 \\
Youngstown & -67.0 \\
SOURCE: Oates and Schwab (1997, Table 3). & \\
\hline
\end{tabular}

tax unchanged should have no effect on building activity. It is also worth noting, however, that according to Oates and Schwab, the city of Pittsburgh granted tax cuts for new building construction. These tax cuts essentially indirectly lowered the tax rate on new (but not on existing) buildings.

Suggestive evidence concerning the impact of Pittsburgh's change in tax rates is presented in Table 2, which shows the percentage change in average annual value of building permits for 15 cities between the two periods 1960-79 and 198089. Excluding Pittsburgh, which had a greater than 70 percent increase in average annual building permits between these two periods, and Columbus, which had a 15 percent increase, all 13 other cities experienced a decrease in building permits between these two periods.

To generate stronger evidence, Oates and Schwab also used an econometric model to test the impact of structural change that may have occurred in 1979-80 when the city of Pittsburgh 
increased the land/buildings tax differential. For each of the 15 cities listed in Table 2, Oates and Schwab ran regressions with the real value of building permits against a constant and a dummy variable. This dummy variable took a value of zero for years prior to 1980 and a value of 1 for 1980 and later. They found that the coefficient on the dummy variable was both positive and statistically significant only in the regression for the city of Pittsburgh. ${ }^{17}$

To present further evidence on the impact of increasing the land/buildings tax rate differential, Oates and Schwab looked at U.S. Census Bureau data of the metropolitan statistical areas (MSAs) of these 15 cities over the years 1974-89. With these data, they made a distinction between cities and suburbs and between the real values of residential and nonresidential building permits. They ran regressions with these Census data using the same specifications as for the Dun and Bradstreet data, with distinct regressions for residential, nonresidential, and office building permits for each city and its respective suburbs. For the city of Pittsburgh, the post-1979 dummy was significant in the regressions for both the nonresidential and office building permits, but insignificant for the residential regression. ${ }^{18}$ For the Pittsburgh suburb regressions, the post-1979 dummy in the residential permit regression was significant but negative; this dummy was significant but positive in the Pittsburgh suburban office regression, and insignificant in the Pittsburgh suburban nonresidential regression. ${ }^{19}$

These findings reveal a correlation between the 1979-80 tax reforms in Pittsburgh and the subsequent increases in building permits. As mentioned above, however, these findings are far from definitive in light of public finance theory and the specifics of the tax reform in Pittsburgh (that is,

\footnotetext{
17 Oates and Schwab also looked at a slight variation of the aforementioned model, which included a time trend in addition to the other variables. They found that the coefficient on the post-1979 dummy variable was positive and statistically significant only in the Pittsburgh and Buffalo regressions.

18 The signs and significance of these variables are the same for the similar specifications that include time trends.

${ }^{19}$ Once again, the signs and significance of these variables are robust to the inclusion of a time trend in these regressions.
}

the fact that the tax on buildings was unchanged when the tax on land was raised). ${ }^{20}$

\section{Short-Run Initial Effects}

Because Virginia is a state whose citizens have shown much interest in two-rate taxation, Bowman and Bell (2004) used data on individual property parcels from three Virginia locations to estimate property tax liabilities using a tax in which only the unimproved land is taxed. Consequently, Bowman and Bell were able to identify the initial change in the real property tax liabilities of taxpayers resulting from a shift to a pure land tax, a limiting case of two-rate taxation, from the current uniform tax on land and improvements. The three areas examined vary substantially from each other. Roanoke, a city of roughly 100,000 residents, has been slowly losing population, yet has experienced job growth. Chesterfield County, a bedroom county in the Richmond area with over 250,000 residents, has grown both in terms of population and jobs. Highland County, a small rural county of less than 2,500 residents, has experienced declines in both population and jobs.

Regardless of the area, Bowman and Bell found that owners of properties with high landto-improvements ratios will tend to experience an increase in their tax liabilities with the move to two-rate taxation, while owners of properties with low land-to-improvements ratios will tend to experience a decrease in their tax liabilities. Generally speaking, owners of residential property, especially owners of multi-unit housing properties, would tend to benefit. In addition, the researchers found that, even within a specific classification of land use, substantial differences in distributional effects were likely.

\section{Simulation Studies}

The limited use of two-rate taxation has motivated a number of informative simulation studies

\footnotetext{
20 The Pittsburgh City Council removed the two-rate system in 2000. Craig (2003) reports that construction spending in the city was higher in the two years prior to rescission than the two years after. Construction activity in the city was also lower than in the surrounding suburbs and in the United States as a whole after the rescission.
} 
to generate information about its potential effects. It is important to stress, similar to Kodrzycki (1998), some important caveats about simulation studies. Computable general equilibrium models, which provide the foundation for simulation studies, provide a range of answers to policy questions because the appropriate structure of the underlying model and the choice of parameter values are subject to much uncertainty. ${ }^{21}$ Here we focus on three studies. These studies provide insights into the economic consequences of land value and two-rate taxation in a variety of situations.

Nechyba (2001) has explored the economic impacts of land tax reforms for each U.S. state as well as for an average state. Numerous revenueneutral reforms were examined; in other words, the increase in revenues from increased taxes on unimproved land exactly matches the decrease in tax revenues from reducing some distortionary tax on capital or labor. Generally speaking, based on the likely change in land prices, Nechyba found that reforms eliminating entire classes of taxes are feasible in nearly all states. The political prospects for passing a specific reform are better in states with high per capita taxes and low per capita incomes and when the reform is targeted to lowering taxes on capital rather than labor. In addition, reforms targeted to lowering taxes on capital cause either increases in land prices or modest declines, while reforms targeted to lowering taxes on labor tend to cause large declines in land prices.

The second study we examine was done by England (2003). He undertook a simulation study using county-level data that examined a revenueneutral shift for New Hampshire from a uniform property tax to a land value tax. The shift of the tax burden from capital to land reduces the disposable income of owners of land, some of which is

\footnotetext{
${ }^{21}$ For example, Kodrzycki (1998) highlights the importance of the elasticity of substitution between land and capital, which is the optimal response of the capital/land ratio to a change in the relative prices of these inputs. When this elasticity equals 0.25 , Nechyba (1998) finds that the substitution of land taxes for capital taxes leads to an increase of 43 percent in the capital/land ratio and 32 percent in national output. Meanwhile, a higher value of this elasticity, 0.5, is associated with a more than doubling of the capital/land ratio and an 89 percent increase in national output.
}

likely borne by nonresidents. The reduction in disposable income leads to reduced consumer spending on items other than housing services. These impacts, however, are more than offset by the changes set in motion by the decline in the cost of owning residential buildings as well as commercial and industrial capital. As a result, residential construction and business investment spending are boosted. Overall, employment and gross state product increase in New Hampshire, both immediately and after ten years. Moreover, each of New Hampshire's ten counties is projected to have higher output, income, employment, and population a decade after the tax change. While all counties benefit, the economic changes for the county that benefits the most are roughly double those of the county benefiting the least.

The final study we examine was done by Haughwout (2004), who estimates the consequences for New York City of replacing its current tax system with a land tax. Two situations are examined. In one case all taxes are eliminated with the exception of the land tax, which is maintained at its current rate. In the other case, the key difference is that the tax rate on land is increased so that total tax revenue is maintained.

In the first case, the distortions caused by taxes are eliminated and overall tax burdens are reduced. At the same time, tax revenues decline, so the provision of public goods falls correspondingly. Overall, New York City experiences substantial increases in private output, private capital stock, employment, land values, and population and a substantial reduction in public good provision and per capita tax revenues.

In the second case, the tax rate on land is increased substantially so that tax revenues are maintained. Contrary to the first case, land prices fall, due in part to the substantially higher land tax rate. Public goods provision is maintained. Similar to the first case, private output, private capital stock, employment, and population rise sharply.

The two cases examined by Haughwout produce a clear message. The potential gains from eliminating the distortions stemming from the taxation of capital and labor, especially in a city in which existing tax rates are relatively high, 


\section{Cohen and Coughlin}

are quite large. Such a conclusion leads quite naturally to the issue of why two-rate taxation is rarely used.

\section{IMPLEMENTING TWO-RATE TAXATION: SOME PRACTICAL PROBLEMS}

In opposition to the theory and evidence of the potential gains from using two-rate taxation, a number of practical problems face a region that decides to implement two-rate taxation. These problems include valuing land accurately, determining the revenue potential of land value taxation, and providing sufficient public infrastructure to support the increased economic activity.

To impose different tax rates on improvements to land and raw land, one must have estimates of the value of the improvements and the value of raw land. Netzer (1998), using an in-depth examination of land value data, concluded that nonagricultural land values could not be trusted. Moreover, the data were incomplete with respect to timing and coverage. Therefore, practically speaking, useful land value data for two-rate taxation purposes do not exist.

As Mills (1998) has stressed, to preclude distortions, a land tax must be applied to the value of land prior to any improvements. Defining exactly what raw land is presents problems. When a parcel of land is ready to be developed, it has already been improved substantially. Preparing land for development generally requires a number of costly activities, such as clearing and leveling the land, conducting environmental tests, surveying, obtaining the required permits, and installing underground infrastructure. Furthermore, the value of raw land hinges on the state of technology as well as on the state of urban and rural development. For example, agricultural inventions have affected the value of rural land, while construction innovations have affected the value of urban land. It remains to be seen how developments in information technology will affect land values. The bottom line is that estimating the value of raw land, which is likely to change over time, is very challenging.
Even more challenging is the assessment of land values of developed properties. With respect to commercial property, Mills (1998) notes the sites and the structures are owned by different groups. The separate ownership is frequently driven by tax considerations, with the site owned by an untaxed organization and the structure owned by a business in a high tax bracket that can utilize the benefits of depreciation. In theory, separate estimates of site and structure values of developed properties could be generated using an approach known as hedonic pricing. Such an approach is commonly used to explain, in a statistical sense, housing prices. The sales price of a house is related to the characteristics of the house (i.e., living space, number of bathrooms, age, etc.), lot size, the neighborhood, and the community.

Applying hedonic pricing to commercial properties is problematic. Difficulties would arise because of a lack of agreement as to which characteristics should be included, the paucity of transactions, and the fact that many transactions are not arms-length exchanges. Consequently, generating accurate estimates of raw land values, an essential component of land taxation, is difficult; uniform taxation may be preferred because it is less costly to use than two-rate taxation. ${ }^{22}$ However, whether the additional administrative cost is large or small is unclear. Netzer (1998) has noted that, despite the fact that each parcel of land is unique, the difference in value for adjacent parcels is minimal, a fact that should ease the administrative burden.

The absence of accurate land value data makes it difficult to answer the question of whether land value taxation would generate sufficient revenues to be an important replacement for revenues from conventional property taxes. Despite the lack of land value data, Netzer (1998) and McGuire (1998) find that Pittsburgh's experience with two-rate taxation suggests that land value taxation can generate an adequate level of tax revenue. On the other hand, Mills (1998) is doubtful. His reasoning is straightforward: Annual real estate taxes are 1.5 to 2.0 percent of the market value of tax-

\footnotetext{
22 One way to overcome this problem, suggested by Anas (1998), is to have the city purchase and demolish some buildings and then sell the land.
} 
able property and site values are estimated to be, at most, 10 percent of property values. If site and structure rents are capitalized at the same rate, gross-of-tax site rents are, at most, 1 percent of property values. Consequently, a 100 percent land rent tax would not generate sufficient revenue to replace the revenue from existing real estate taxes.

A land tax rate of 100 percent of the land rent is equivalent to land confiscation without assuming the liabilities of ownership. Mills (1998) has noted that courts have consistently ruled that similar regulations or taxes require, based on the Fifth Amendment, that owners be compensated for their losses. Such a court decision would negate the value of using the land tax. While it is unlikely that proponents of two-rate taxation would argue for a tax rate of 100 percent on land, there remains a question as to what percentage of land rent could be taxed away without substantially affecting an owner's incentive to seek the best use for the land. At some tax rate, major misallocations of land use would result.

Another potential problem occurs as a result of the increased economic activity that takes place, assuming the successful implementation of land taxation. The resulting increase in the building/ land and employment/land ratios would necessitate increased infrastructure provided by government, such as transportation facilities and schools. Without transportation infrastructure, increased traffic congestion could negate the potential benefits of land taxation. The unanswered question is whether the political process would be responsive to the changed environment in the private sector. In light of the increased activity, many would downplay this situation as a problem, but rather view it as an opportunity.

\section{THE POLITICAL ECONOMY OF TWO-RATE TAXATION}

A strong case exists that two-rate taxation is more efficient than, and thus preferable to, uniform taxation. A reasonable question is why uniform taxation remains the norm. In addition to the practical problems discussed in the preced- ing section, a number of explanations have been proposed. These explanations fall into either of two general categories-one stressing that the efficiency gains are likely to be elusive and another stressing that opposition from those likely to be harmed by the change to a two-rate system prevents such a change.

\section{Efficiency}

We begin with a discussion of the arguments based on efficiency. Lee (2003) has shown that uniform taxation of land and capital may be more efficient than the taxation of land only. This possibility arises when some land in a taxing jurisdiction is owned by nonresidents. In terms of public policy, a specific jurisdiction is assumed to structure its fiscal policies in the interests of its residents. Thus, one might argue that tax policies are made with minimal consideration for the wellbeing of absentee owners because nonresidents do not vote in the jurisdiction. One consequence is that the jurisdiction taxes land excessively to exploit absentee owners and the resulting funds are used to overprovide public goods. ${ }^{23}$ One way to mitigate the inefficiency of overtaxing land is for a higher-level government to require jurisdictions to tax land and capital at a uniform rate. This is what occurs in the United States because most state governments do not allow lower-level governments to deviate from uniform taxation.

Another argument suggesting the desirability of uniform taxation has been made by Wildasin and Wilson (1998). They start with the observation that the returns to land are risky under production uncertainty. This feature of the economy provides an incentive for individuals to diversify their risk by owning land in multiple jurisdictions. However, if each jurisdiction eliminates the rent on owning land with 100 percent tax rates on land, the benefits of diversification are eliminated.

\footnotetext{
${ }^{23}$ Public goods, according to Rosen (1995, p. 61), are goods characterized by "non-rival consumption." Nonrival consumption exists when one person's consumption of the good does not reduce its availability to anyone else. Common examples are national defense, lighthouses, roads, and parks. Note that for roads and parks, at some point, as more and more individuals attempt to enjoy the services of roads and parks congestion costs arise; when this occurs, consumption is no longer nonrival.
} 


\section{Cohen and Coughlin}

Therefore, uniform taxation allows for benefits from diversification and may be superior to the pure land tax.

\section{Opposition}

The argument that political opposition would mount against the change from uniform taxation to two-rate taxation is straightforward. The change in taxation will create winners and losers. Owners of properties with high land-to-improvements ratios (e.g., car dealerships) will tend to experience an increase in their tax liabilities with the move to two-rate taxation, while owners of properties with low land-to-improvements ratios (e.g., highrise office buildings) will tend to experience a decrease in their tax liabilities. The owners of substantial amounts of land are likely to be wealthy and may have a disproportionate voice in the political process and, thus, prevent a change that would harm them.

The preceding discussion suggests that communities with heterogeneous consumer preferences and incomes might be unlikely candidates to adopt a land tax. On the other hand, more homogeneous areas, such as a suburban community, are more likely candidates for adoption. However, as Hamilton (1976) and Fischel (1998) have noted, these more homogeneous communities are also likely to be less afflicted by distortionary taxes.

A fundamental question concerns how tworate taxation can be introduced so as to reduce the political opposition. England (2004) runs simulations using tax parcel data and shows that the opposition to tax reform will likely be reduced if, as part of the introduction of two-rate taxation, uniform property tax credits are also introduced.

Before completing our discussion concerning opposition to two-rate taxation, a few points about the knowledge of policymakers are warranted. A lack of understanding of two-rate taxation on the part of political leaders likely is not a reason for the limited use of the two-rate tax in states and localities in the United States. Brunori (2004) conducted a survey of state, county, and city officials and received about 1200 responses. The results indicate that between 65 and 70 percent of the respondents were "very or somewhat familiar" with land value taxation, and about 65 to 67 percent of these political leaders responded the same for the two-rate tax. About 76 percent of city and county government officials and over 62 percent of state lawmakers thought that a two-rate tax would enhance economic development. According to Brunori, over 40 percent of political leaders who responded held a common "misperception" that the two-rate tax system would lead to greater sprawl, due to additional building on undeveloped suburban land stemming from the reduction in the tax rate on structures.

\section{CONCLUSION}

Proponents of two-rate taxation stress that the taxation of real property involves two taxes. One falls on man-made capital, such as buildings, while the other falls on land, which is provided by nature. The taxation of capital tends to deter its formation. The higher the tax rate is in a specific location, the larger the incentive for investors to direct their capital elsewhere. The taxation of land, however, does not deter either the formation of land or encourage its relocation because land is essentially fixed in quantity and immobile. Therefore, the taxation of land does not generate the changes in behavior that one sees with the taxation of capital. This differential effect of taxation provides a justification for real property taxation that taxes buildings and land at different rates.

The theoretical gains associated with a revenue-neutral movement from single-rate taxation of real property to two-rate taxation are subject to little controversy. Gains arise in the form of declines in the deadweight losses associated with taxation and increases in overall economic activity. Parcels of land within a city would tend to be used more productively. However, the size of the gains associated with specific two-rate proposals is subject to much uncertainty. For example, the study of Pittsburgh's experience with two-rate taxation by Oates and Schwab (1997) and a number of simulation studies have suggested that the gains can be substantial. On the other hand, the paucity of experience with two-rate taxation, the sensitivity of the results of simulation studies to the underlying model's structure and the choice 
of parameter values, and concerns about administrative feasibility raise questions about the size of the gains that could be realized.

The majority of legislators are familiar with the theoretical consequences of two-rate taxation. However, the fact that few regions use two-rate taxation reflects the existence of significant obstacles. First, the practical implementation of tworate taxation complicates the assessment process because the value of land must be separated from the value of improvements. Second, significant political opposition to two-rate taxation arises because the change to two-rate taxation causes some individuals to suffer adverse distributional consequences; generally speaking, owners of property with high land-to-improvement ratios tend to be harmed, while owners of property with low land-to-improvement ratios tend to benefit. In light of these consequences, policies that mitigate the adverse effects, yet allow for the capture of the economic gains, are required to reduce the opposition to two-rate taxation and increase the prospects for adoption.

Given the current system of taxation in the United States, pressures for using two-rate taxation will likely continue to emerge at the local level. It remains to be seen, however, whether the opinions of Nobel Prize winners Milton Friedman and William Vickrey concerning land taxation will become widely held by legislators and voters.

\section{REFERENCES}

Anas, Alex. "Commentary," in Dick Netzer, ed., Land Value Taxation: Can It and Will It Work Today? Cambridge, MA: Lincoln Institute of Land Policy, 1998, pp. 49-59.

Bowman, John H. and Bell, Michael E. "Implications of a Split-Rate Real Property Tax: An Initial Look at Three Virginia Local Government Areas.” Working Paper WP04JB1, Lincoln Institute of Land Policy, 2004.

Bromley, Daniel W. "Commentary," in Dick Netzer, ed., Land Value Taxation: Can It and Will It Work Today? Cambridge, MA: Lincoln Institute of Land Policy, 1998, pp. 24-30.
Brueckner, Jan K. "Property Taxation and Urban Sprawl," in Wallace E. Oates, ed., Property Taxation and Local Government Finance: Essays in Honor of C. Lowell Harriss. Cambridge, MA: Lincoln Institute of Land Policy, 2001, pp. 153-72.

Brunori, David. "What Politicians Know About Land Taxation." Land Lines, October 2004, 16(4); www.lincolninst.edu/pubs/pub-detail.asp?id=972.

Craig, Eleanor D. "Land Value Taxes and Wilmington, Delaware: A Case Study," Proceedings of the National Tax Association's 96th Annual Conference on Taxation, November 14, 2003, pp. 275-78; www.buec.udel.edu/craige/nta-lvt.htm.

England, Richard W. "State and Local Impacts of a Revenue-Neutral Shift from a Uniform Property to a Land Value Tax: Results of a Simulation Study." Land Economics, February 2003, 79(1), pp. 38-43.

England, Richard W. "An Essay on the Political Economy of Two-Rate Property Taxation.” Working Paper WP04RE1, Lincoln Institute of Land Policy, 2004.

Fischel, William A. "The Ethics of Land Value Taxation Revisited: Has the Millennium Arrived Without Anyone Noticing?” in Dick Netzer, ed., Land Value Taxation: Can It and Will It Work Today? Cambridge, MA: Lincoln Institute of Land Policy, 1998, pp. 1-23.

George, Henry. Progress and Poverty. New York: Schalkenbach Foundation, [1879] 1954.

Hamilton, Bruce W. "Capitalization of Intrajurisdictional Differences in Local Tax Prices." American Economic Review, December 1976, 66(5), pp. 743-53.

Harriss, C. Lowell. “Taxing for Progress.” Unpublished manuscript, June 2003.

Hartzok, Alanna. "Pennsylvania's Success with Local Property Tax Reform: The Split Rate Tax." The American Journal of Economics and Sociology, April 1997, 56(2), pp. 205-13. 


\section{Cohen and Coughlin}

Haughwout, Andrew F. "Land Taxation in New York City: A General Equilibrium Analysis," in Amy Ellen Schwartz, ed., City Taxes, City Spending: Essays in Honor of Dick Netzer. London: Edward Elgar, 2004.

Kodrzycki, Yolanda K. "Replacing Capital Taxes with Land Taxes: Efficiency and Distributional Implications with an Application to the United States Economy: Commentary,” in Dick Netzer, ed., Land Value Taxation: Can It and Will It Work Today? Cambridge, MA: Lincoln Institute of Land Policy, 1998, pp. 205-09.

Lee, Kangoh. "Should Land and Capital Be Taxed at a Uniform Rate?" Canadian Journal of Economics, May 2003, 36(2), pp. 350-72.

Mankiw, N. Gregory. Principles of Economics. Mason, OH: Thompson/South-Western, 2004.

McGuire, Therese J. "The Relevance and Feasibility of Land Value Taxation in the Rich Countries: Commentary," in Dick Netzer, ed., Land Value Taxation: Can It and Will It Work Today? Cambridge, MA: Lincoln Institute of Land Policy, 1998, pp. 137-40.

Mills, Edwin S. "The Economic Consequences of a Land Tax," in Dick Netzer, ed., Land Value Taxation: Can It and Will It Work Today? Cambridge, MA: Lincoln Institute of Land Policy, 1998, pp. 3148.

Nechyba, Thomas. "Replacing Capital Taxes with Land Taxes: Efficiency and Distributional Implications with an Application to the United States Economy," in Dick Netzer, ed., Land Value Taxation: Can It and Will It Work Today? Cambridge, MA: Lincoln Institute of Land Policy, 1998, pp. 183-204.

Nechyba, Thomas. "Prospects for Land Rent Taxes in State and Local Tax Reform.” Working paper, Lincoln Institute of Land Policy, 2001.
Netzer, Dick. "The Relevance and Feasibility of Land Value Taxation in the Rich Countries," in Dick Netzer, ed., Land Value Taxation: Can It and Will It Work Today? Cambridge, MA: Lincoln Institute of Land Policy, 1998, pp. 109-36.

Oates, Wallace E. and Schwab, Robert M. “The Impact of Urban Land Taxation: The Pittsburgh Experience." National Tax Journal, March 1997, 50(1), pp. 1-21.

O’Sullivan, Arthur. Urban Economics. Fifth Edition. New York: McGraw-Hill/Irwin, 2003.

Pennsylvania Department of Community and Economic Development, Commonwealth of Pennsylvania. Taxation Manual. Eighth Edition. October 2002;

www.inventpa.com/docs/Document/application/ pdf/9ab7d259-e9a3-4340-af5b-a5deed9757aa/ taxation.pdf.

Pennsylvania Manual, Commonwealth of Pennsylvania. Section 6: Local Government. Volume 116, 2003; www.dgs.state.pa.us/pamanual/ lib/pamanual/sec6/section6a.pdf.

Rosen, Harvey S. Public Finance. Fourth Edition. Chicago: Irwin, 1995.

Rybeck, Walter. "United States," in Robert V. Andelson, ed., Land Value Taxation Around the World. Chap. 9. Malden, MA: Blackwell Publishers, 2000.

Vickrey, William. "Simplifications, Progression, and a Level Playing Field," in Kenneth Wenzer, ed., Land Value Taxation: The Equitable and Efficient Source of Public Finance. Armonk, NY: M.E. Sharpe, 1999, pp. 17-23.

Wildasin, David E. and Wilson, John Douglas. "Risky Local Tax Bases: Risk-Pooling vs. Rent-Capture.” Journal of Public Economics, August 1998, 69(2), pp. 229-47. 